\title{
Pengembangan Modul IPA Kelas VI dengan Model Cooperative Learning
}

\author{
Moh Shobirin \\ Universitas PGRI Adi Buana, Pascasarjana, Teknologi Pendidikan
}

\section{Edcomtech}

\section{Jurnal Kajian}

Teknologi Pendidikan

Volume 5, No 1, April 2020

24-37

Submitted 27-08-2019

Accepted 31-10-2019

Corresponding Author

Moh Shobirin

mohshobirin064@gmail.com

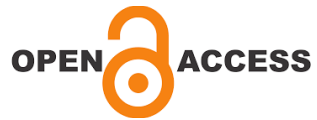

\begin{abstract}
Abstrak
Penelitian ini bertujuan menghasilkan Modul IPA dengan Model Cooperatif Learning kelas VI yang dirancang lebih menarik, melatih mandiri, kreatif dan inovasi, sesuai kebutuhan siswa serta mengembangkan kompetensi, karakter dan literasi siswa. Metode pengembangan yang digunakan Dick, Carey \& Carey, disesuaikan desain pembelajaran. Jenis data dalam penelitian ini adalah (1) hasil validasi ahli desain pembelajaran, dan ahli isi/ materi (2) hasil uji teman sejawat, (3) data hasil uji coba lapangan. Teknik analisis ini digunakan untuk mengolah data yang diperoleh melalui lembar evaluasi dalam bentuk deskriptif dan mengukur kevalidan menggunakan rumus yang telah ditentukan. Hasil validasi dari ahli materi mencapai skor kevalidan 3,5. Sedangkan dari ahli desain pembelajaran materi bahan ajar yang dikembangkan skor kevalidan 3,64. Hasil Uji Teman sejawat terhadap materi mencapai skor kevalidan 3,6. Sedangkan hasil uji coba pada siswa secara keseluruhan kevalidan bahan ajar mencapai 3,55. Dari data dan analisis yang telah dilakukan dapat disimpulkan bahwa produk pengembangan Modul IPA dengan Model Cooperatif Learning dapat dijadikan sebagai bahan ajar pada mata pelajaran IPA kelas VI Sekolah Dasar yang mencapai kevalidan sangat valid, dan mampu mengembangkan ranah berpikir kritis, kreatif, kerjasama dan mampu menyelesaikan masalah.
\end{abstract}

Kata Kunci: cooperative learning, modul IPA sekolah dasar

\begin{abstract}
This study aims to produce a Science Module with a Class VI Cooperative Learning Model that is designed to be more interesting, to train independently, creatively and innovatively, according to students 'needs and develop students' competence, character and literacy. The development model used by Dick, Carey \& Carey. The selection of this model is based on the theoretical foundation of learning design. The type of data used in this study are (1) the results of the validation of the learning design expert, and the content / material expert (2) the results of the peer testing, (3) the data from the field trial results. This analysis technique is used to process data obtained through evaluation sheets in descriptive form and measure validity using predetermined formulas. The results of the validation of the material experts reached a validity score of 3.5. While the learning design expert on teaching materials developed a validity score of 3.64. Peer Test Results for the material reached a validity score of 3.6. While the results of trials on students as a whole the validity of teaching materials reached 3.55. From the data and analysis that has been done, it can be concluded that the product development of the Natural Sciences Module with the Cooperative Learning Model can be used as teaching material in Natural Science classes VI of Primary Schools that reach validity and is very valid, and is able to develop the realm of critical thinking, creative, collaboration and able to complete problem.
\end{abstract}

Keywords: cooperative learning, elementary school science modules, process skills 


\section{PENDAHULUAN}

Dalam dunia kerja saat ini setiap individu dituntut memiliki kecakapan hidup baik hard skill maupun soft skill yang mumpuni. Hal diakibatkan karena memasuki abad 21 dituntut untuk siap berkompetisi dimanapun berada. Pada abad 21 setiap individu harus memiliki kemampuan pada aspek keterampilan. Menurut Bernie Trilling dan Charles Fadel (2009:48): Ada tiga perangkat keterampilan yang diperlukan di abad ke-21: pertama, keterampilan belajar dan inovasi, kedua, kemampuan mengolah informasi, media dan teknologi, ketiga, keterampilan hidup dan karier.

Melihat realitas yang demikian akan berpengaruh dalam dunia pendidikan khususnya pada proses pembelajaran. Maka diperlukan sebuah terobosan baru dalam menggunakan media pembelajaran yang menarik, kreatif, inovatif dan sesuai kebutuhan siswa. Karena kemajuan teknologi yang berkembang begitu pesat, manusia bisa mencari informasi dan berkomunikasi tanpa da batas.

Tantangan pembelajaran diatas, sejalan dengan gagasan pemerintah dengan membuat kurikulum 2013. Salah satu rasionalitas pelaksanaan kurikulum itu didasari perkembangan teknologi yang mengharuskan bangsa ini memiliki kompetensi, berpikir kritis, kreatif, dan mampu menyelesaikan masalah. Sehingga dalam pelaksanaan pembelajaran bisa mengkaitkan nilai karakter, literasi, dan mampu menghadapi tantangan abad 21 4C (communication, colaboratif, creative, critical thingking) (Kemendikbud, 2013:5).

Pengembangan Kurikulum 2013 pada hakekatnya didasarkan perubahan arus globalisasi, permasalahan lingkungan, dan kemjuan teknologi menjadi tantangan masa depan. (Suyantiningsih, Isniatun, \& Sisca, 2016, p-1). Senada pendapat Putri, Mimien, dan Mohamad (2017;p. 292) Tuntutan pembelajaran pada Kurikulum 2013 yaitu pembelajaran berbasis kompetensi, ketrampilan dan karakter bangsa.

Untuk mencapai tujuan arah baru kebijakan kurikulum 2013 dan paparan diatas, maka diperlukan suatu kegiatan pembelajaran berpusat pada siswa, mengedepankan kerjasama, berpikir kritis dan memecahkan masalah. Bahan ajar adalah Point penting dalam keberhasilan dalam proses pembelajaran di kelas.

Bahan ajar merupakan bagian penting dalam kegiatan belajar mengajar di samping komponen lain, yaitu guru, siswa, metode pembelajaran, dan penilaian. Menurut Ridwan $(2016 ; 168)$ Bahan ajar sebagai salah satu elemen penting untuk membangkitkan motivasi dan minat belajar siswa, dan mendukung pencapaian tujuan belajar.

Menurut Prastowo (2012:17) bahan ajar adalah segala bahan yang disusun secara sistematis, yang mengacu pada dan digunakan dalam proses pembelajaran untuk mencapai tujuan pembelajaran. Senada dengan Lestari (2013: 2) bahan ajar adalah seperangkat materi pelajaran yang dibuat berdasarkan kompetensi telah ditentukan.

Sedangkan pendapat Majid (2013: 174), bentuk bahan ajar setidaknya dapat dikelompokkan menjadi empat yaitu: (1) Bahan cetak misalnya handout, buku, dan modul. (2) Bahan ajar audio contoh kaset, radio, dan compact disk audio. (3) Bahan ajar audio visual seperti video compact disk, film. (4) Bahan ajar interaktif contohnya compact disk interaktif.

Modul adalah salah satu bagian dari bahan ajar yang dapat menunjang kegiatan pembelajaran. Depdiknas (2008:31) menyatakan bahwa modul adalah satu bentuk bahan ajar yang didesain secara utuh dan sistematis yang dapat digunakan untuk belajar secara mandiri tanpa dengan bimbingan guru. Rayandra Asyar (2012: 155) mengatakan bahwa modul adalah bahan ajar berbasis cetakan yang dirancang untuk belajar secara mandiri oleh peserta didik yang dilengkapi oleh petunjuk untuk belajar sendiri. Peserta didik dapat belajar sendiri tanpa kehadiran guru secara langsung.

Sementara itu menurut Abdul Majid (2006:176) modul adalah sebuah buku yang didesain secara menarik dengan tujuan agar peserta didik dapat belajar secara mandiri tanpa atau dengan bimbingan guru, sehingga modul berisi seluruh komponen materi 
yang telah diajarkan. Sedangkan menurut S. Nasution (2005: 205) mengemukakan bahwa yang dimaksud dengan modul adalah seperangakat materi lengkap lengkap yang berdiri sendiri dan terdiri atas suatu rangkaian kegiatan belajar dengan maksud membantu peserta didik mencapai tujuan yang diharapkan.

Pembelajaran menggunakan modul menurut Nana Syaodih Sukmadinata dan Erliana Syaodih (2012:97) menekankan pembelajaran secara individual, disesuaikan dengan kecepatan dengan kemampuan masing-masing. Akan tetapi ada tugas-tugas tertentu yang menuntut peserta didik harus bekerja sama dalam kelompok, Dengan demikian kerjasama dalam kelompok (kooperatif) tetap ada dalampembelajaran.

Proses pembelajaran IPA pada umumnya menekankan pada prinsip lingkungan alam sekitar. Cara memahami alam sekitar dengan tepat dapat dilakukan dengan pengamatan, penelitian, untuk menemukan konsep yang riil dan nyata. Pengetahuan tentang alam sekitar diharapkan dapat menjadi pedoman bagi siswa untuk mengetahui ciri makhluk hidup. Sejauh ini perlu adanya daya dukung mulai dari sarana, prasarana yang berfungsi sebagai pedoman untuk melakukan pengamatan tentang ciri makhluk hidup terhadap lingkungannya.

Berdasarkan observasi yang dilakukan di SDN Kalanganyar Kecamatan Sedati, guru menggunakan buku dari penerbit dan menggunakan lembar kerja Siswa (LKS). Hasil pengamatan, bahan ajar yang digunakan kurang menekakan siswa untuk belajar secara mandiri, dan tahapan-tahapan proses pembelajaran masih kurang dan tidak kontekstual. Sebagai dampaknya proses pembelajaran kurang menarik. Melihat fakta di atas, maka perlu dikembangkan bahan ajar berupa modul IPA dengan model Cooperatif Learning di SDN Kalanganyar Kecamatan Sedati.

Ada beberapa hasil penelitian menunjukan bahwa pengajaran oleh teman sebaya dengan model Cooperative learning lebih efektif. Prinsip Cooperative learning adalah alur proses belajar tidak harus berasal dari guru menuju siswa. Tetapi siswa juga memiliki potensi untuk saling mengajar siswa yang lain dalam bentuk peer teaching. (Anita Lie,2003).

Menurut Slavin (dalam Rusdi, 1998) Cooperative learning merupakan pendekatan pembelajaran, siswa dituntut bekerja dalam suatu kelompok yang berbeda-beda. Perbedaaan kelompok ditinjau dari berbagai aspek, seperti kemampuan akademis, jenis kelamin, rnaupun status sosial. Dalam hal ini Burden dan Byrd (1999:99) rnerurnuskan "cooperative learning is a means of grouping students in small, mixed ability learning teams. The teacher present the group with a problem to solve or task to perform. Student in the group the work among themselves, help one anothe, praise and critize one another's contributions. Students work in group of four to six member cooperate with each other to learn the material".

Berdasarkan pendapat di atas maka dapat dikenali beberapa pembelajaran yang menggunakan pembelajaran cooperative, yakni (a) siswa belajar dalam suatu kelompok, dimana setiap kelompok bisa terdiri empat sampai enam orang; (b) terjadi heteregon kelompok, yang merupakn gabungan antara yang bekemampuan tinggi, sedang atau rendah; (c) disajikan permasalahan untuk dipecahkan solusinya, (d) melatih siswa dalam penyelesaian masalah .

Rusdi (1998) menyatakan bahwa dalam cooperative learning terdapat dua hal yang menarik. Pertama, melatih sikap kompetisi siswa, karena lingkungan kehidupan saat ini yang serba bersaing. Kedua, Prestasi akademis, keterampilan sosial dan harga diri dapat diraih siswa jika cooperative learning.

Pendekatan pembelajaran kooperatif, sangat membantu kondisi siswa yang heterogen. Menurut pendapat Arends (dalam Sabat Saragih, 2002) pendekaatan ini bisa membantu satu dengan lainnya. Bagi siswa yang tidak bisa, dapat berinteraksi dengan yang bisa, keduanya saling bertukar informasi. Siswa yang sudah bisa ada kepuasaan bisa membantu siswa yang belum bisa.

Menurut Slavin (dalam Anita Lee, 2003) cooperative learning melatih siswa untuk 
menyampaikan pendapat, bekerja sama, dan belajar untuk bertanggungjawab. Metode cooperative learning memiliki prinsip tujuan dan kesuksesan tim diutamakan. Tiga konsep pokok untuk semua metode cooperative learning adalah kerjasama dalam kelompok, tanggung jawab, semua siswa hak yang sama untuk sukses, dan penghargaan terhadap kelompok bagi yang mencapai tujuan tim.

Pembelajaran dengan mengedepankan kerjasama tim dan mengembangkan daya nalar siswa untuk melatih daya kritis, dan metode pemecahan masalah adalah sebuah kebutuhan pada Abad 21 ini. Stategi pembelajaran IPA atau sains yang tepat pada abad 21 menurut Hosnan (2014: 37) memiliki karakteristik sebagai berikut: (1) peserta didik menjadi titik sentral (2) mengintegrasikan proses sains dalam mengkontruksi konsep, (3) melatih daya nalar tingkat tinggi pada kemampuan siswa (4) dapat mengembangkan karakter peserta didik.

Oleh karena itu diperlukan sebuah inovasi dan pengembangan modul IPA yang digunakan dalam pembelajaran siswa kelas VI di SD Negeri Kalanganyar. Pengembangan modul IPA dengan model cooperatif learning. ini dimaksudkan agar siswa bisa lebih tertarik dan mudah memahami materi IPA khususnya dalam mempersiapkan diri untuk menghadapi ujian nasional.

\section{METODE}

Penelitian dan pengembangan ini menghasilkan produk berupa Modul IPA dengan model Cooperatif Learning. Model pengembangan bahan ajar ini adalah model pengembanganDick,Carey\& Carey (2001)yang didesain sesuai kebutuhan pengembangan. Menurut Handayani $(2017 ; 18)$ Model desain pembelajaran yang dikembangkan oleh Dick, Carey \& Carey harus dijalankan secara prosedural, artinya disesuaikan dengan langkah-langkah yang harus di tempuh secara berurutan. Pemilihan model ini berdasarkan landasan teoritis desain pembelajaran. Sedangkan Menurut Degeng (dalam Wahyuni $(2018 ; 107)$ menyampaikan bahwa bahan ajar harus dirancang dengan model pengembangan tertentu, dan memasukkan materi pembelajaran dari berbagai sumber karena dengan perancangan yang baik akan mempengaruhi kualitas pembelajaran. Bahan ajar yang dirancang dengan baik dapat mempengaruhi hasil belajar siswa (Resvathi, Degeng, N.S dan Kuswandi: 2017).

Tahapan dalam pengembangan modul ini, yaitu: mengidentifikasi tujuan instruksional umum, melakukan analisis pembelajaran, mengidentifikasi prilaku dan karakteristik siswa, merumuskan Tujuan Pembelajaran Khusus, mengembangkan item-item tes acuan patokan, mengembangkan strategi pembelajaran, mengembangkan dan menulis bahan pembelajaran, mendesain dan melaksanakan evaluasi formatif, merevisi kegiatan.

Agar modul ini proses pengembangan bisa digunakan sebagai media pembelajaran yang efektif sesuai harapan, maka perlu untuk dilakukan validasi dan uji coba terlebih dulu. Oleh karena itu modul yang telah disusun dan ditulis divalidasi dan diuji coba dalam beberapa tahap, yaitu: Pertama, validasi ahli materi/isi, bertujuan untuk mendapatkan data berupa penilaian, pendapat dan saran terhadap kelayakan isi, kelayakan penyajian, kelayakan bahasa dalam modul yang akan dibuat. Kedua, Validasi ahli desain pembelajaran, bertujuan untuk mendapatkan penilaian komentar serta saran terhadap ketepatan desain pembelajaran dan ilustasi isi dalam pembelajaran.

Ketiga, Uji Teman Sejawat, bertujuan untuk mendapatkan masukan dan saran terhadap isi ketepatan isi materi dan tugas yang diberikan pada siswa dapat membantu pemahaman siswa. Selain itu juga untuk mengukur apakah bahan ajar ini memudahkan guru dalam mengajar materi di kelas. Keempat, Uji coba lapangan, bertujuan untuk mendapatkan situasi belajar yang sesungguhnya dalam pembelajaran. Tahap akhir ini untuk menilai apakah ada daya tarik belajar pada siswa, dan apakah modul yang telah dikembangkan dapat digunakan dalam pembelajaran di kelas sesuai harapan.

Jenis data yang digunakan dalam penelitian ini adalah hasil validasi ahli desain 
pembelajaran, hasil validasi ahli isi, hasil masukan dari teman sejawat, dan data hasil uji coba lapangan. Sedangkan teknik analisis data ini adalah analisis isi. Analisis ini untuk mengelompokkan informasi data kualitatif dari hasil lembar evaluasi ahli media, ahli materi/isi, ahli desain pembelajaran, lembar evaluasi yang diisi oleh siswa dan guru, hasil diskusi, hasil konsultasi, yang berupa masukan, tanggapan, dan saran perbaikan yang diterima. Sedangkan data kuantitatif yang diperoleh dianalisis dengan teknik deskriptif untuk mengetahui kevalidannya

Agar mengetahui hasil interval rata-rata skor dan kategori kevalidan dari penilaian modul yang telah divalidasi oleh ahli materi bidang studi IPA, maka dilakukan penghitungan dengan menggunakan rumus sebagai berikut:

$$
\mathbf{R}=\frac{\sum \text { (Skor validator) }}{\sum \text { (Butir penilaian) }}
$$

Untuk dapat memberikan makna dan pengambilan keputusan tingkat kevalidan modul digunakan ketetapan sebagai berikut:

Tabel 1. Kriteria kevalidan modul. (Arikunto, 2013)

\begin{tabular}{c|l}
\hline $\begin{array}{c}\text { Interval } \\
\text { Rata-rata Skor }\end{array}$ & Kategori Kevalidan \\
\hline $3 \leq \mathrm{VR} \leq 4$ & Sangat Valid \\
\hline $2 \leq \mathrm{VR}<3$ & Valid \\
\hline $1 \leq \mathrm{VR}<2$ & Kurang Valid \\
\hline
\end{tabular}

Ket: VR adalah rata-rata hasil dari penilaian validator

\section{HASIL DAN PEMBAHASAN}

Hasil pengembangan produk modul IPA dengan Cooperatif Learning ditampilkan bagian penting atau keunggulannya diantaranya sebagai berikut;

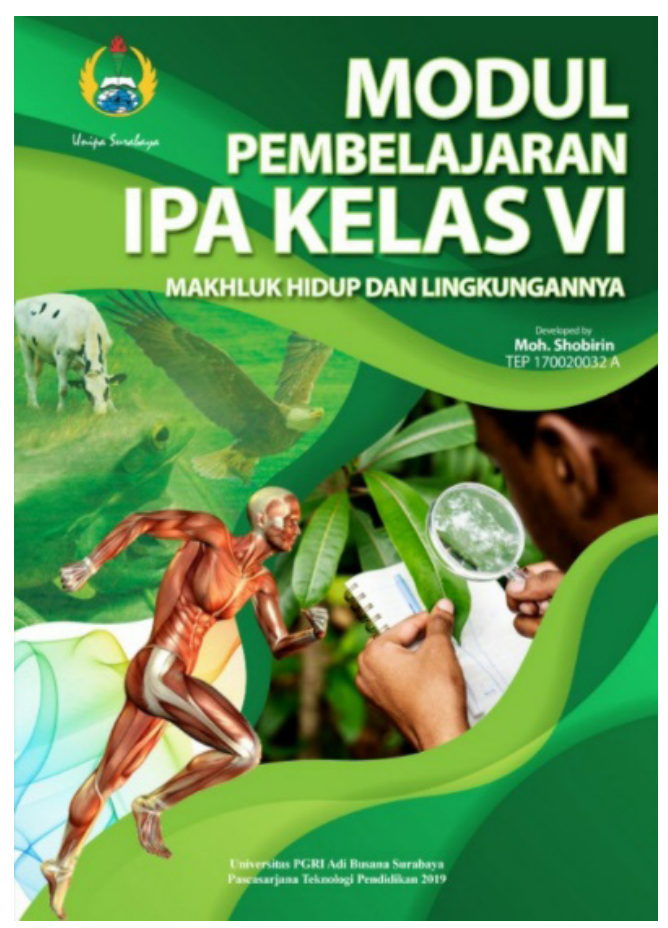

Gambar 1. Cover depan Modul

Setiap awal bab diberi desain menarik

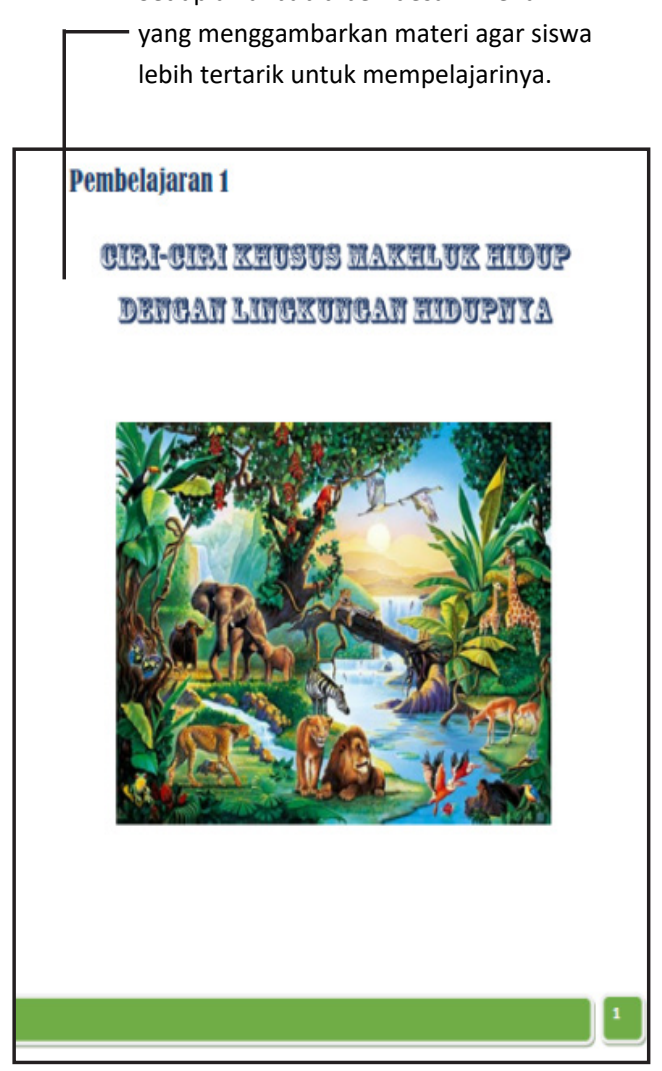

Gambar 2. Sub Judul 
Fitur Peta konsep untuk mempermudah pemahaman dan alur pembahasan sehingga membawa siswa untuk lebih belajar efektif

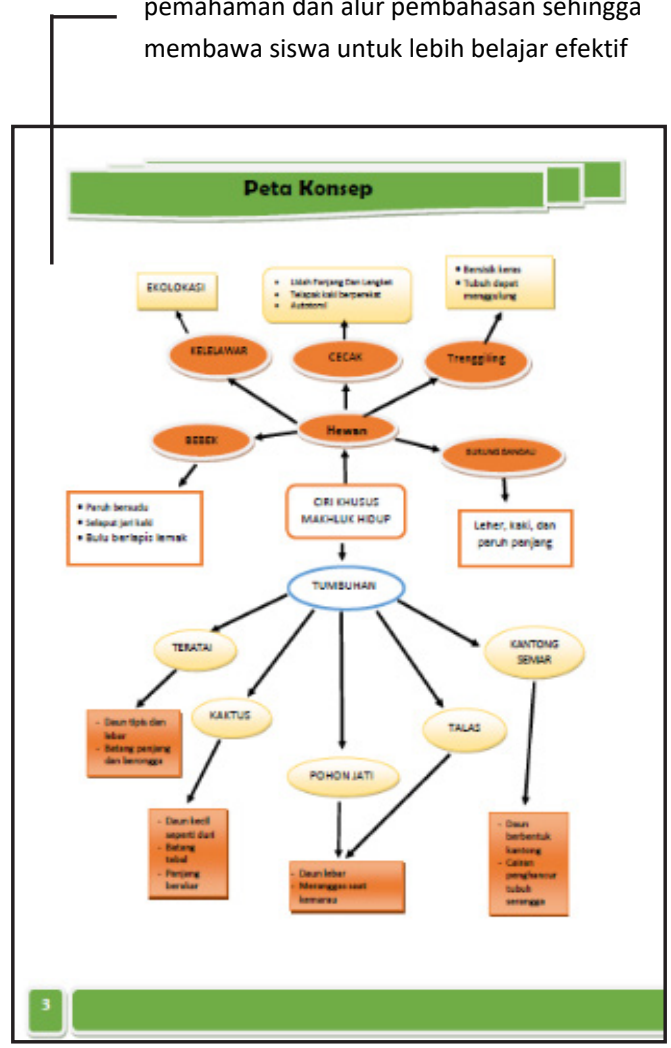

\section{Gambar 3. Peta Konsep}

Sebelum pembelajaran dimulai, selalu diawali apersepsi dengan maksud sebagai koneksi

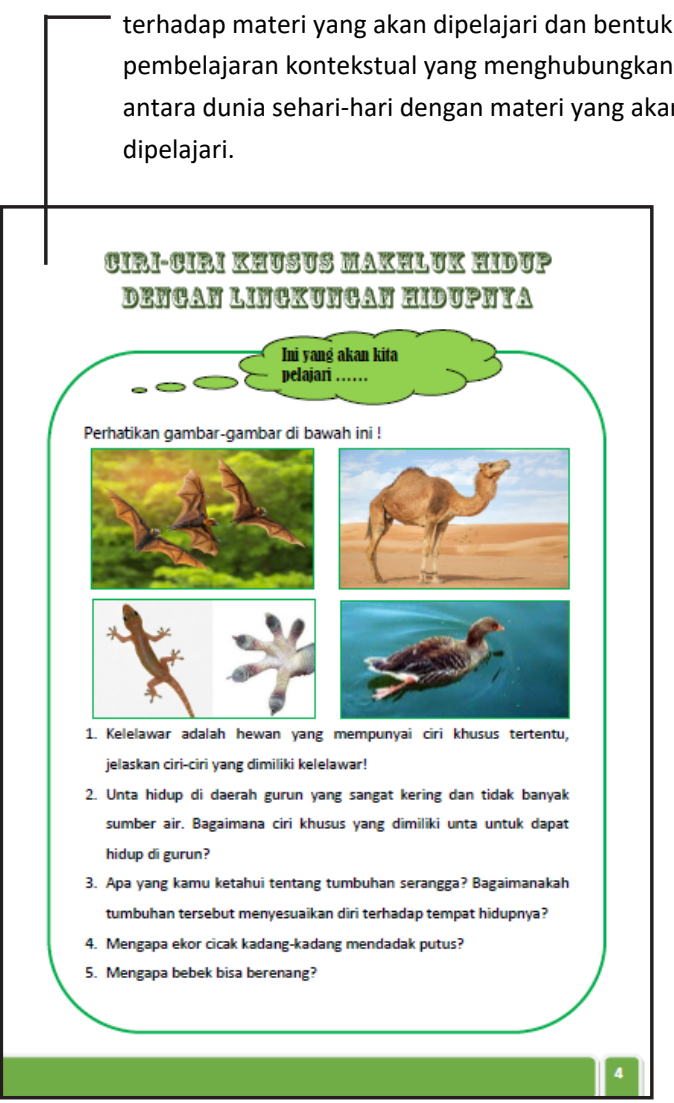

Gambar 4. Apersepsi
Kegiatan pembelajaran kooperatif dengan melakukan pengamatan dan menganalisis secara kelompok. Pada kegiatan ini ditekankan pada kerjasama kelompok dalam pembuatan laporan hasil pengamatan

Makhluk hidup dapat mempertahankan hidupnya melalui dua cara, yaitu memenuhi kebutuhan makan dan melindungi diri dari gangguan makhluk hidup lain atau pemangsanya. Agar dapat mempertahankan hidupnya setiap makhluk hidup mempunyai cara yang berbeda-beda. Cara yang berbeda antara makhluk hidup satu dengan lainya ini bisa disebut dengan ciri-ciri khusus. Ciri-ciri khusus dalam suatu makhluk hidup adalah untuk mempertahankan hidup didalam lingkunganya.

\section{Ciri Khusus hewan}

Dalam dunia hewan, ada hewan pemangsa (predator) dan hewan yang dimangsa. Oleh karena itu, hewan harus dapat mempertahankan hidupnya agar tidak mudah dimangsa oleh hewan lain sehingga dapat mempertahankan

Beberapa jenis hewan mempunyai ciri khusus untuk menyesuaikan diri terhadap lingkunganya. Kemampuan hewan untuk menyesuaikan diri dengan lingkunganya disebut adaptasi.

Agar kita memahami tentang ciri-ciri pada beberapa hewan, coba lakukan kegiatan berikut ini!

\section{$\sum$ Kegiatan $1=$}

Mengamati Ciri Khusus Hewan dan Fungsinya

Coba amati beberapa hewan disekitarmu seperti, cicak, ayam, bebek, kelelawar, dan hewan lain yang kamu ketahui. Buatlah daftar hasil pengamatanmu dalam bentuk tabel seperti berikut ini !

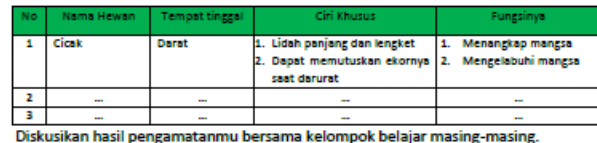

\section{Gambar 5. Cooperative Learning}

Fitur Tes Formatif sebagai alat evaluasi pembelajaran pada sub bab yang telah dipelajari. Sehingga kemampuan siswa dapat terukut dengan jelas.

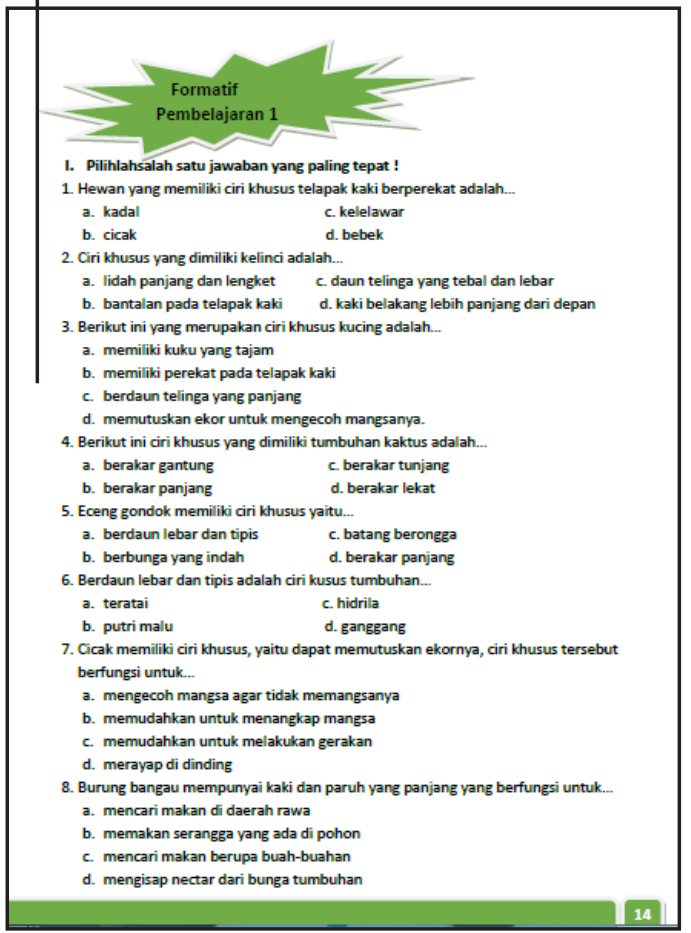

Gambar 6. Tes Formatif 

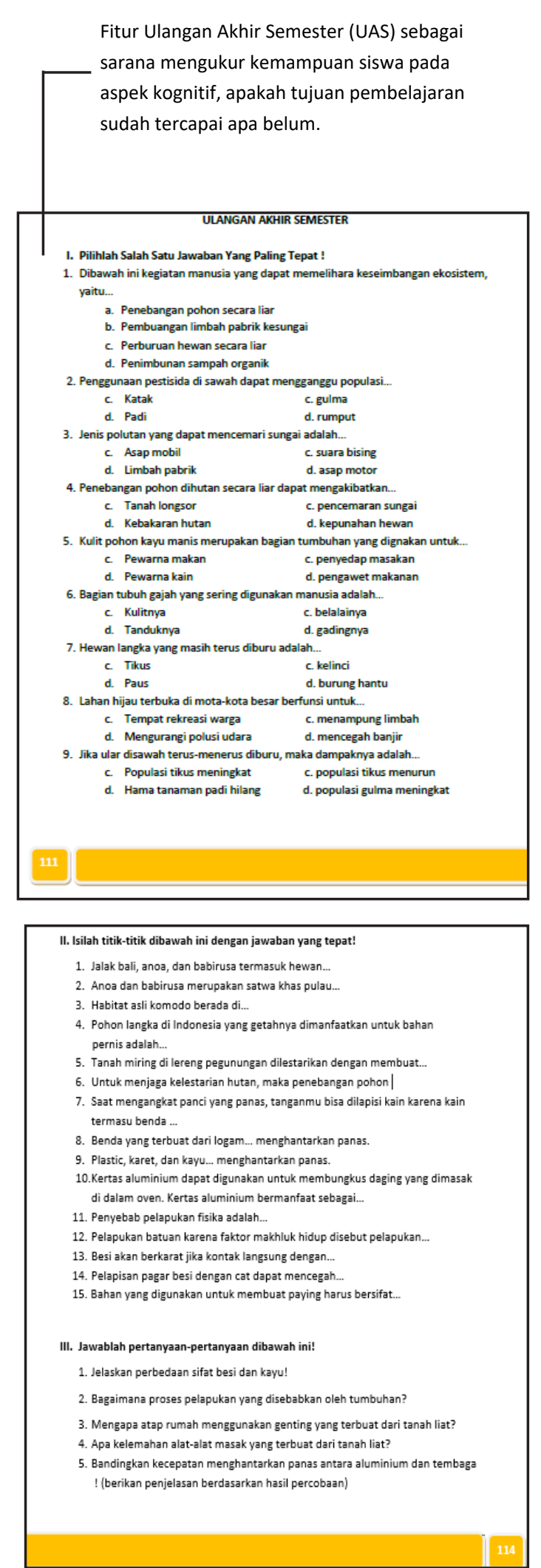

Gambar 7. Uji Kompetensi

\section{Hasil Uji Ahli Materi IPA}

Produk pengembangan buku modul IPA kelas VI materi Makhluk Hidup dan Lingkunganya yang sudah selesai, selanjutnya diberikan kepada ahli materi atau ahli bidang studi IPA kelas VI untuk mendapatkan review, penilaian, serta saran-saran dengan menggunakan angket/ kuesioner. Produk pengembangan berupa buku modul IPA kelas VI materi Makhluk Hidup dan Lingkunganya telah divalidasi ahli materi pada tanggal 12 Maret 2019 oleh Bapak Dr. Ir. Pungky Slamet Wisnu Kusuma, M.Si, seorang dosen Pascasarjana Universitas PGRI Adi Buana.

Berikut ini adalah hasil yang diperoleh dari ahli materi. Penilaian ahli materi berupa angka 1 sampai dengan 4 .

\section{Tabel 2: Rekap Penilaian ahli materi pada Modul IPA Kelas VI}

\begin{tabular}{c|l|l|l}
\hline No. & Aspek Penilaian & $\begin{array}{c}\text { Butir } \\
\text { Penilaian }\end{array}$ & $\begin{array}{c}\text { Skor } \\
\text { Penilian }\end{array}$ \\
\hline 1. & Kelayakan Isi & 12 & 43 \\
\hline 2. & $\begin{array}{l}\text { Kelayakan } \\
\text { penyajian materi }\end{array}$ & 7 & 23 \\
\hline 3. & Kelayakan Bahasa & 9 & 33 \\
\hline & Skor Total & 28 & 99 \\
\hline
\end{tabular}

Berdasarkan hasil penilaian ahli materi yang tertera pada tabel 2 diatas, maka dapat disimpulkan bahwa nilai atau skor ratarata yang diperoleh terhadap komponenkomponen buku modul IPA kelas VI adalah berdasarkan tabel 2 kriteria pengkategorian kevalidan modul ini.

Untuk mengetahui hasil interval rata-rata skor dan kategori kevalidan dari penilaian buku ajar yang telah divalidasi oleh ahli materi bidang studi IPA, maka dilakukan penghitungan dengan menggunakan rumus sebagai berikut:

$$
\begin{aligned}
\mathbf{V R} & =\frac{\left.\sum \text { (Skor validator }\right)}{\left.\sum \text { (Butir penilaian }\right)} \\
\mathrm{VR} & =\frac{43+23+33}{12+7+9} \\
\mathrm{VR} & =\frac{99}{28} \\
\mathbf{V R} & =\mathbf{3 , 5}
\end{aligned}
$$


Dari hasil penghitungan rumus di atas diperoleh hasil $V R=3,5$ untuk penilaian buku ajar dari ahli materi bidang studi IPA. Berdasarkan tabel kriteria pengkategorian kevalidan buku ajar nilai skor VR $=3,5$ berada dalam interval ( $3 \leq \mathrm{VR} \leq 4)$, maka tingkat kevalidan buku ajar tentang isi materi dapat dikatakan sangat valid.

Berdasarkan hasil dari penilaian dan saran dari ahli materi bidang studi IPA, maka perlu adanya revisi atau perbaikan agar produk pengembangan dapat menjadi lebih baik. Adapun masukan dari Ahli materi adalah sebagai berikut; Pertama, aspek kelayakan isi; Kedalaman materi perlu diperdalam kembali dengan contoh dan uji coba, sehingga pemahaman siswa lebih luas, Keakuratan konsep dan definisi perlu diperjelas lagi, Keakuratan huruf dalam sebuah istilah masih ada yang belum lengkap, Gambar dan ilustrasi harus ditulis sumbernya, serta penjelasan nama gambar. Kedua, aspek kelayakan penyajian. Kesimpulan materi yang dipelajari setiap pembelajaran harusnya lebih spesifik sehingga memudahkan pemahaman pembaca, Perlu ada soal UTS dan UAS sebagai evaluasi kemampuan pemahan siswa, ketertautan antar kegiatan belajar perlu dikaji lagi agar ada kesinambungan antara materi satu dengan materi berikutnya. Ketiga, pada aspek kelayakan bahasa; Perlu adanya revisi kalimat, sehingga lebih efektif, dan materi harus disesuaikan dengan tingkat perkembangan emosional siswa.

\section{Hasil uji Ahli Desain Pembelajaran}

Setelah validasi dilakukan oleh ahli materi atau ahli bidang studi IPA, maka langkah selanjutnya adalah validasi dari ahli Media pembelajaran dengan menggunakan angket/ kuesioner. Review pada tahap ini bertujuan untuk mendapatkan data yang berupa penilaian, pendapat, maupun saran terhadap produk pengembangan, dan komponenkomponen desain pengembangan. Produk pengembangan berupa buku modul IPA kelas VI untuk materi makhluk hidup dan lingkunganya telah divalidasi ahli media pada tanggal 19 Maret 2019 oleh Bapak Dr. H. Ibut Priono Leksono, M.Pd, seorang dosen pascasarjana pada program teknologi pendidikan Universitas PGRI Adi Buana Surabaya. Data yang diperoleh dari ahli media berupa data kuantitatif (angka) dan data kualitatif (saran/ masukan) terhadapa produk pengembangan. Untuk itu perlu disajikan komponen-komponen validasi yang dilakukan oleh ahli media seperti tabel berikut:

Tabel 3. Rekap Hasil Uji Ahli Desain Pembelajaran

\begin{tabular}{c|l|l|l}
\hline No. & Aspek Penilaian & $\begin{array}{c}\text { Butir } \\
\text { Penilaian }\end{array}$ & $\begin{array}{c}\text { Skor } \\
\text { Penilian }\end{array}$ \\
\hline 1. & Ukuran Modul & 8 & 7 \\
\hline 2. & $\begin{array}{l}\text { Desain Sampul } \\
\text { Modul }\end{array}$ & 7 & 26 \\
\hline 3. & Desain Isi Modul & 10 & 58 \\
\hline & Skor Total & 25 & 91 \\
\hline
\end{tabular}

Berdasarkan hasil penilaian ahli media yang tertera pada tabel 3 diatas, maka dapat disimpulkan bahwa nilai atau skor ratarata yang diperoleh terhadap komponenkomponen modul. Untuk mengetahui hasil interval rata-rata skor dan kategori kevalidan dari penilaian modul yang telah divalidasi oleh ahli media, maka dilakukan penghitungan dengan menggunakan rumus sebagai berikut:

$$
\begin{aligned}
\mathbf{V R} & =\frac{\sum(\text { Skor validator })}{\sum(\text { Butir penilaian })} \\
\mathrm{VR} & =\frac{91}{25} \\
\mathrm{VR} & =\mathbf{3 , 6 4}
\end{aligned}
$$

Dari hasil penghitungan rumus di atas diperoleh hasil VR $=3,64$ untuk penilaian modul dari ahli desian. Berdasarkan tabel kriteria pengkategorian kevalidan modul nilai skor VR $=3,64$ berada dalam interval ( $3 \leq \mathrm{VR}$ $\leq 4)$, maka tingkat kevalidan modul tentang aspek kelayakan kegrafikan yang terdiri dari ukuran modul, desain sampul dan desain isi dapat dikatakan sangat valid.

Ada beberapa masukan dari ahli media yang perlu direvisi antara lain; Ukuran modul perlu dikurangi sedikit sehingga lebih menarik dan sesuai dengan isi materi, warna latar belakang sebaiknya lebih gelap sedikit sehingga warna 
judul modul terlihat kontras, bentuk, warna ukuran, proporsi modul diupayakan sesuai dengan realita, pemisahan antar paragraf dalam sebuah kalimat harus jelas, penempatan hiasan pada halaman sebaiknya lebih diperhatikan, dan penggunaan gambar atau media lebih diperhatikan nilai seni dan budayanya.

\section{Hasil Penilaian Teman Sejawat}

Selain diuji kelayakan melalui ahli materi dan ahli media, produk pengembangan modul IPA kelas VI materi makhluk hidup dan lingkunganya juga meminta penilaian kepada teman sejawat. Penilaian dilakukan pada tanggal 16 April 2019. Teman sejawat yang dimaksud adalah Pengawas TK-SD dan Koordinator Wilayah Dinas Pendidikan dan Kebudayaan Kecamatan sedati, yang bergelar S-2 di lingkungan sekitar peneliti. Teman sejawat yang dimaksud bernama Siti Hamidah, S.Pd, M.Pd lulusan S-2 Teknologi Pendidikan Universitas PGRI Adi Buana Surabaya dan sekarang masih aktif menjadi pengawas TK-SD dan mempunyai jabatan tambahan sebagai Koordinator Wilayah Dinas Pendidikan dan Kebudayaan Kecamatan Sedati serta menjdi dosen UT PGTK dan PGSD Surabaya wilayah kecamatan Waru Kabupaten Sidoarjo. Teman sejawat tersebut akan dimintai pendapat tentang isi materi dari produk buku ajar berupa angket validasi materi untuk mendapatkan review, penilaian, serta saran-saran.

Tabel 4. Rekap Hasil Penilaian Teman sejawat

\begin{tabular}{c|l|l|l}
\hline No. & Aspek Penilaian & $\begin{array}{c}\text { Butir } \\
\text { Penilaian }\end{array}$ & $\begin{array}{c}\text { Skor } \\
\text { Penilian }\end{array}$ \\
\hline 1. & Kelayakan Isi & 12 & 44 \\
\hline 2. & $\begin{array}{l}\text { Kelayakan } \\
\text { penyajian materi }\end{array}$ & 7 & 24 \\
\hline 3. & Kelayakan Bahasa & 9 & 33 \\
\hline & Skor Total & 28 & 101 \\
\hline
\end{tabular}

Untuk mengetahui hasil interval rata-rata skor dan kategori kevalidan dari penilaian modul yang telah dinilai oleh teman sejawat, maka dilakukan perhitungan dengan menggunakan rumus sebagai berikut:

$$
\begin{aligned}
& \mathbf{V R}=\frac{\left.\sum \text { (Skor validator }\right)}{\sum(\text { Butir penilaian })} \\
& \mathrm{VR}=\frac{44+24+33}{12+7+9} \\
& \mathrm{VR}=\frac{101}{28} \\
& \mathbf{V R}=\mathbf{3 , 6}
\end{aligned}
$$

Dari hasil penghitungan rumus di atas diperoleh hasil VR $=3,6$ untuk penilaian buku ajar dari teman sejawat. Berdasarkan tabel kriteria pengkategorian kevalidan buku ajar nilai skor $\mathrm{VR}=3,6$ berada dalam interval ( 3 $\leq \mathrm{VR} \leq 4$ ), maka tingkat kevalidan buku ajar tentang isi materi dapat dikatakan sangat valid.

\section{Hasil Uji Lapangan Pada Siswa}

Hasil pengembangan produk yang telah mendapatkan penilaian, saran, masukan dan revisi dari ahli materi, ahli media dan teman sejawat kemudian diujikan kepada kelompok kecil yang berjumlah 12 orang peserta didik kelas VI SDN Kalanganyar kecamatan Sedati Kabupaten sidoarjo. 12 orang peserta didik tersebut terdiri dari 4 orang peserta didik dengan kemampuan tinggi, 4 orang peserta didik dari kemampuan menengah, dan 4 orang peserta didik dari berkemampuan rendah. Pengujian tersebut dilakukan dengan tujuan sejauh mana produk pengembangan ini layak, mendukung, dan menarik bagi mereka selaku pengguna dari produk pengembangan ini serta untuk dilakukannya perbaikan berdasarkan saran atau respon yang peserta didik berikan sehingga saat di gunakan dalam pembelajaran modul yang dinilai sudah sesuai dengan kebutuhan peserta didik.

Produk pengembangan ini diujikan kepada peserta didik kelas VI SDN Kalanganyar tersebut diserahkan pada tanggal 23 April 2019, data yang diperoleh dari hasil uji coba lapangan adalah sebagai berikut: 
Tabel 5; Hasil Rekap Uji Lapangan

\begin{tabular}{c|l|l|l|l}
\hline No. & \multicolumn{1}{|c|}{$\begin{array}{c}\text { Aspek } \\
\text { Penilaian }\end{array}$} & $\begin{array}{c}\text { Butir } \\
\text { Penilaian }\end{array}$ & $\begin{array}{c}\text { Skor } \\
\text { Penilian }\end{array}$ & Persen \\
\hline 1. & Ketertarikan & 5 & 17,6 & $88 \%$ \\
\hline 2. & $\begin{array}{l}\text { Kelayakan } \\
\text { Penyajian } \\
\text { materi }\end{array}$ & 4 & 14,2 & $89 \%$ \\
\hline 3. & $\begin{array}{l}\text { Kelayakan } \\
\text { Bahasa }\end{array}$ & 3 & 10,9 & $90 \%$ \\
\hline & Skor Total & 12 & 42,7 & $89 \%$ \\
\hline
\end{tabular}

Untuk mengetahui hasil interval rata-rata skor dan kategori kevalidan dari penilaian modul yang telah direspon oleh 12 siswa kelas VI SDN Kalanganyar di atas, maka dilakukan perhitungan dengan menggunakan rumus sebagai berikut:

$$
\begin{aligned}
& \mathbf{V R}=\frac{\left.\sum \text { (Skor rata }- \text { rata }\right)}{\sum(\text { Butir penilaian })} \\
& \mathrm{VR}=\frac{17,6+14,2+10,9}{12} \\
& \mathrm{VR}=\frac{42,7}{12} \\
& \mathrm{VR}=\mathbf{3 , 5 5}
\end{aligned}
$$

Dari hasil penghitungan rumus di atas diperoleh hasil VR $=3,6$ untuk penilaian buku ajar uji kelompok kecil. Berdasarkan tabel kriteria pengkategorian kevalidan modul nilai skor VR $=3,6$ berada dalam interval $(3 \leq \mathrm{VR} \leq$ 4), maka tingkat kevalidan modul tentang isi materi dapat dikatakan sangat valid.

Secara keseluruhan hasil validasi ahli terdiri dari ahli materi, ahli desain pembelajaran, uji teman sejawat, dan uji lapangan menunjukkan hasil yang baik. uji validasi materi dilakukan oleh dosen Universitas Adi Buana Surabaya mendapatkan rerata 3,5 dengan kategori sangat valid, indikator penilaian materi meliputi : kelayakan isi yang disajikan terkandung dalam Kompetensi Dasar (KD), yang mendapat skor $89,6 \%$, hal ini disebabkan oleh materi yang disajikan di dalam modul sudah sesuai dengan kompetensi dasar (KD) dalam kurikulum 2013. Hal ini senada dengan pendapat Prastowo (2015), kompetensi dasar yang tercantum dalam modul diambil dari pedoman khusus kurikulum 2013.
Selanjutnya indikator keluasan materi yang disajikan mendukung pencapaian kompetensi dasar, yang mendapatkan skor $82,1 \%$, hal ini disebabkan oleh materi yang disajikan di dalam modul dapat mendukung pencapaian kompetensi dasar, Prastowo (2015), mengatakan bahwa materi atau isi modul akan sangat bergantung pada kompetensi dasar yang akan dicapai.

Selanjutnya indikator kedalaman materi yang disajikan sesuai dengan tujuan yang hendak dicapai, mendapat skor $88,3 \%$ hal ini disebabkan materi yang disajikan di dalam modul sesuai dengan tingkat pendidikan SD/ MI. Hasil diatas, sesuai dengan pendapat Rahdiyanta (2017) mengatakan bahwa materi berisi uraian pengetahuan tentang kompetensi yang sedang dipelajari.

Indikator keakuratan fakta dan data yang disajikan sesuai dengan kenyataan dan efisien untuk meningkatkan pemahaman peserta didik, indikator tersebut mendapatkan skor 98\% hal ini disebabkan di dalam modul data disajikan sesuai dengan kondisi fisik atau fakta yang ada di sekitar lingkungan peserta didik, seperti gambar yang disajikan dalam modul merupakan gambar-gambar yang sering mereka temui dalam kehidupan sehari-hari, sehingga modul pembelajaran IPA yang dikembangkan dapat meningkatkan pemahaman peserta didik, hal ini sesuai dengan Rahdiyanta (2017) mengatakan bahwa penulisan modul bertujuan untuk meningkatkan motivasi dan gairah belajar siswa.

Indikator keakuratan contoh dan kasus sesuai kenyataan dan efisien untuk pemahaman peserta didik, yang mendapatkan skor 94\%, hal ini dikarenakan modul IPA yang dikembangkan terdapat contoh-contoh atau kasus yang sesuai dengan kenyataan sebagaimana pendapat Rahdiyanta (2017) bahwa modul harus tersedia contoh dan ilustrasi yang mendukung kejelasan pemaparan materi pembelajaran. Indikator selanjutnya keakuratan gambar yang disajikan sesuai dengan kenyataan dan efisien untuk meningkatkan pemahaman peserta didik, di dalam modul terdapat gambar-gambar yang disajikan sesuai dengan kenyataan dan 
lingkungan sekitar peserta didik, seperti contoh gambar yang terdapat di dalam modul misalkan contoh gambar fase kehidupan manusia yang mempelajari perkembangan manusia sehingga menimbulkan daya tarik untuk mempelajarinya, karena sesuai dengan pendapat Prastowo (2015), mengatakan bahwa gambar-gambar yang disajikan di dalam modul tidak hanya dapat mendukung penjelasan materi, tetapi untuk dapat menambah daya tarik dan mengurangi rasa kebosanan. Indikator gambar dan ilustrasi yang disajikan terdapat dalam kehidupan sehari-hari, dan dilengkapi penjelasan, pada indikator tersebut mendapatkan skor 92\% hal ini dikarenakan gambar yang disajikan dalam modul sesuai dengan kehidupan sehari-hari kemudian setiap gambar yang disajikan terdapat penjelasan mengenai gambar tersebut, hal ini sesuai dengan pendapat Prastowo (2015), mengatakan bahwa terdapat gambar di dalam modul dan penjelasan materinya.

Indikator menciptakan kemampuan bertanya yang disajikan dalam uraian, yang mendapatkan skor $96 \%$ hal ini sesuai dengan yang terdapat di modul bahwa uraian materi yang disajikan dapat menciptakan kemampuan peserta didik untuk bertanya. Indikator selanjutnya, terdapat latihan atau contoh-contoh kasus, yang mendapatkan skor 98\% hal ini sesuai dengan karakteristik modul bahwa soal latihan tugas atau sejenisnya yang memungkinkan untuk mengukur pemahaman siswa (Rahdiyanta, 2017).

Sedangkan hasil Analisa Uji validasi desain dilakukan oleh Dr. H. Ibut Priono Leksono, M.Pd, seorang dosen pascasarjana pada program teknologi pendidikan Universitas PGRI Adi Buana dengan memperoleh skor 3,64 dengan kategori sangat valid. Penjelasan penilaian tiap-tiap indikator sebagai berikut: indikator ukuran modul, ukuran yang digunakan modul IPA materi hubungan mahluk hidup dan lingkungannya, sesuai dengan standar ISO yaitu B5 (176 x $250 \mathrm{~mm})$ sesuai dengan pedoman penyusunan modul dalam (BSNP, 2016) selanjutnya indikator ilustrasi modul yang mendapatkan skor $100 \%$, hal ini dikarenakan ilustrasi yang terdapat dalam modul mampu mengungkapkan materi sesuai dengan kenyataan dan disajikan dalam bentuk kreatif dan menarik, dan peneliti mengambil gambar langung sesuai dengan materi yang disajikan hal ini sesuai dengan panduan (BSNP, 2016).

Pada hasil uji validasi oleh teman sejawat yang mendapatkan $V R=3,6$ berada dalam interval ( $3 \leq \mathrm{VR} \leq 4)$, maka tingkat kevalidan buku ajar tentang isi materi dapat dikatakan sangat valid yang ditunjukkan pada indikator, mencakup materi yang ada dalam kurikulum 2013, kelengkapan modul pembelajaran yang sesuai dengan Widodo (Asyhar, 2011) pembuatan modul harus disesuaikan dengan kriteria-kriteria yang telah ditetapkan dan harus dilakukan secara sistematis, sesuai dengan kaidah-kaidah yang baik.

Berdasarkan penilaian ahli materi skor rata-rata 3,5 yang dikategorikan sangat valid, penilaian ahli desain skor rerata 3,6 yang dikategorikan sangat valid, penilaian teman sejawat skor rerata 3,6 yang dikategorikan sangat valid, dan hasil uji coba lapangan skor rerata 3,57 yang dikategorikan sangat valid. Penilaian secara umum mengenai pengembangan modul IPA dengan model cooperative learning, dapat dikatakan sangat valid oleh validator. Hal ini sejalan dengan hasil penelitian (Astika, 2014) yang menyatakan bahwa modul yang berkualitas dilihat dari aspek kevalidan apabila menunjukkan kategori sangat valid atau valid dari penilaian para validator ahli.

Jika dianalisis angket respon siswa terdiri dari ketertarikan modul, penyajian materi kelayakan Bahasa. Pada aspek ketertarikan modul terdiri; a) modul lebih menarik dengan skor (100\%), b) modul membuat semangat dengan skor (98\%), modul membuat belajar tidak membosankan skor (80\%), c) modul memudahkan dalam belajardengan skor (84\%), d) Ilustrasi gambar memberi motivasi mendapat skor (83\%). Hasil rerata pada aspek ketertarikan mencapai $89 \%$, sehingga dapat dikategorikan sangat baik. Hal ini 
dikarenakan pemilihan jenis huruf dan font, menjadikan modul lebih menarik. Hal ini sesuai dengan pernyataan (Prastowo, 2015), yang mengatakan bahwa peneliti harus berani mencoba membuat modul inovatif dan menarik, misalkan dengan penggunaan variasi format tampilan fisik, dan menggunakan jenis dan ukuran font yang berbeda.

Sedangkan aspek kelayakan materi yang terdiri dari; a) Modul terkait kehidupan sehari-hari dengan skor (85\%), b) materi mudah dipahami dengan skor (91\%), c) materi mendorong untuk berdiskusi atau kerjasama skor (94\%), d) modul menguji tingkat pemahaman (83\%). Pada spek kelayakan materi mendapat skor 90,2\% dapat dikategorikan sangat baik. Hal ini disebabkan bahwa modul IPA dengan model cooperative learning mendorong untuk berkerjasama dalam kelompok, sesuai dengan pendapat Slavin (dalam Anita Lee) metode cooperative learning memberikan penghargaan terhadap tim, tanggung jawab terhadap individual dan kesempatan yang sama untuk sukses.

Pada aspek kelayakan bahasa terdiri: a) modul menggunakan bahasa yang mudah dimengerti (88\%); b) petunjuk yang terdapat dalam modul mudah dimengerti (88\%) dan c) pemilihan huruf dan ukuran sangat memudahkan saya dalam membaca (98\%). Penggunaan bahasa pada modul mendapatkan skor rerata (90\%)dengan kategori sangat baik, hal ini dikarenakan bahasa yang disajikan dalam modul, disesuaikan dengan sasaran penggunanya, karena modul ditunjukkan pada siswa SD maka gaya penulisan tidak terlalu formal. $\mathrm{Hal}$ ini sesuai dengan yang diungkapkan Prastowo (2015), yang mengatakan bahwa, gaya penulisan bahan ajar yang dikembangkan harus disesuaikan dengan materi dan kemampuan peserta didik.

Aspek respon siswa selanjutnya yaitu aspek kemenarikan, yaitu : a) Saya menyukai warna yang ada di modul (84.3\%); c) Penyajian modul sangat menarik (81.2\%); c) Saya menjadi bersemangat mengikuti pembelajaran yang ada di modul (86.4\%); d) Saya termotivasi belajar IPA setelah menggunakan modul ini (85.4\%).

\section{SIMPULAN}

Berdasarkan validasi ahli materi dan ahli media, dapat diketahui hasil validasi ahli materi diperoleh VR (rata-rata skor validasi) sebesar 3,5 dan validasi ahli media diperoleh VR (rata-rata skor validasi) sebesar 3,6 sehingga pengembangan modul IPA dengan Cooperatif Learning dapat dikategorikan tingkat kelayakannya dalam segi materi maupun segi media sangat valid/ sangat layak karena berada dalam interval ( $3 \leq \mathrm{VR} \leq 4)$. Didalam penilaiannya, ahli materi dan ahli media memberikan skor 2 (kurang sesuai) pada komponen-komponen tertentu. Namun hal tersebut telah direvisi dan diperbaiki sebagaimana telah dibahas pada bab IV untuk kesempurnaan produk/ buku ajar yang telah dihasilkan.

Selain penilaian dari ahli materi dan ahli media, peneliti juga meminta penilaian kepada teman sejawat dan uji lapangan (terdiri dari 12 siswa) tentang produk yang telah di validasi oleh ahli materi dan ahli media. Dari teman sejawat diperoleh VR sebesar 3,6 dan dari uji lapangan diperoleh VR sebesar 3.55 sehingga produk buku ajar dalam penelitian ini dapat dikategorikan sangat valid/sangat layak untuk dipakai didalam pembelajaran karena berada dalam interval ( $3 \leq \mathrm{VR} \leq 4)$.

Hasil penelitian pengembangan modul IPA dengan Cooperatif Learning, dapat digunakan dalam pembelajaran IPA kelas VI semester I materi makhluk hidup dan lingkungannya, karena modul ini didesain mengembangkan kemampuan siswa dalam bekerja sama, berpikir kritis, dan mampu menyelesaikan masalah. Selain itu dengan adanya modul ini disarankan kepada guru kelas VI untuk mengembangkan produk ini dengan cakupan materi yang lebih luas lagi atau materi yang lain mengingat hasil produk penelitian pengembangan ini dapat memberikan manfaat bagi pembelajaran. 


\section{DAFTAR RUJUKAN}

Agustina Putri , I, Mimien Henie, dan A, Mohamad. 2017. Itegration of Life Skills In Environmen Material To Elevate Learning Achiement. Jurnal Kependidikan. Volume 1, Nomor 2, November 2017, Halaman 291-305.

Anita Lie. 2003. Cooperative Learning: Mematikan Cooperative Learning di ruang-ruang kelas. Jakarta: Grasindo.

Arikunto, S. 2013. Dasar-dasar Evaluasi Pendidikan. Jakarta: Bumi Aksara.

Astika, F. F. 2014. Pengembangan Modul pada Materi Matriks dengan Pendekatan PMRI untuk Siswa Kelas X SMK. Universitas Negeri Yogyakarta.

Bernie Trilling \& Charles Fadel. 2009. 21st Century Skills Learning for Life in Our Times. San Fransisco: Wiley

Badan Penelitian dan Pengembangan. 2013. Pedoman Pelaksanaan Kurikulum 2013. Jakarta: Kementerian Pendidikan dan Kebudayaan.

BSNP, B. S. N. P. 2016. Instrumen Penilaian Buku Teks. Jakarta: Badan Standar Nasional Pendidikan. Available at: http: //bsnp-indonesia. org/ instrumenpenilaian-btp-sd-kelas-iv.

Burden, Paul R, \& Byrd, David M. 1999. Method of effective Teaching. Boston: Allyn and Bacon.

Dick, Walter., Lou Carey \& James O. Carey. 2001. The Systemic Design of Instruction ( $6^{\text {thed) }}$. USA: Harper Collins Publisher.

Handayani, Agustina., Punaji Setyosari.,\& Sulthoni 2017. Pengembangan bahan ajar Biologi Berbasis Multimedia untuk Siswa VIII II SMP Islam Yakin Tutur Kabupaten Pasuruan. Jurnal Kajian Teknologi Pendidikan Edcomtech Volume 2, Nomor 1, April 2017.

Hosnan. 2014. Pendekatan Saintifik dan Kontekstual dalam Pembelaharan Abad 21. Bogor: Ghalia Indonesia

Kemendikbud. 2013. MateriPelatihan Pendidik Impelementasi Kurikulum 2013. Jakarta: Badan Pengembangan SDM Pendidikan dan kebudayaan dan penjaminan mutu Pendidikan Kementrian Pendidikan dan Kebudayaan

Lestari, Ika. 2013. Pengembangan Bahan Ajar Berbasis Kompetensi. Padang:Akademia Permata.

Majid, Abdul. 2013. Strategi Pembelajaran . Remaja Rosdakarya: Bandung.

Nana Syaodih Sukmadinata dan Erliana Syaodih. 2012. Kurikulum Pembelajaran ompetensi. Bandung: PT Refika Aditama

Prastowo, Andi. 2012. Panduan Kreatif Membuat Bahan Ajar Inovatif. Yogyakarta: Diva Press.

P. Resvathi S. A., Degeng, N. S dan Kuswansi, D. 2017. Pengembangan Paket Pembelajaran Penanganan Pascapanen Buah-Buahan Kelas XI Semester II SMKPP Negeri Banjarbaru. Edcomtech Vol. 2 (1), pp. 77-87. Diakses.April 2019

Rahdiyanta, D. 2017. TeknikPenyusunanModul. http://mgmppjoksmpkotabekasi.com/ wpcontent/uploads/2017/04/teknik pembuatan modul.pdf.

Rayandra Asyhar. 2012. Kreatif Mengembangkan Media Pembelajaran. Jakarta: Referensi

Ridwan, M., Sahat Siagian. 2016. Pengembangan Bahan Ajar Pada Mata pelajaran PPKn. Jurnal Teknologi Informasi \& Komunikasi dalam Pendidikan, Vol. 3, No. 2. Desember 2016 halaman167-180. Diakses, 13 April 2019.

Rusdi. 1998. Peningkatan guru dalam Mengorganisasi cooperative learning pada pengajaran matematika SD. Jumal Penelitian Pendidikan Dasar. No. 4. Th II, hlm. 1-10.

Suyantiningsih, M, Isniatun, \& R. Sisca. 2016. Developing Scientific Approach Based Learning Multimedia Integrated With Character Values. Jurnal Kependidikan, Volume 46, Nomor 1, Mei 2016, Halaman 1-13.

S. Nasution. 2005. Berbagai Pendekatan dalam Proses Belajar dan Mengajar. Jakarta: Bumi Aksara 
Sabat Saragih. 2002. Pendekatan Cooperative Learning dalam Pembelajaran Kalkulus dengan menggunakan Peta Konsep. Jumal Kependidikan, No.I, Th.XXXII, hlm. 17- 30.
Wahyuni, Eka., I Nyoman Sudana Degeng., Nurmida, C. Sitompul. (2018), Pengembangan Bahan ajar Tematik Pendamping Guru Dengan Model Webbed Untuk Sekolah Dasar Kelas 2. Jurnal Kajian Teknologi Pendidikan Edcomtech. Vol. 3 No. 22018 